\title{
Integrated Fire Management: Preliminary results and trends in Federal Protected Areas
}

\author{
Camila S. Silva ${ }^{*}$, Sarah C. C. Fontoura ${ }^{l}$, Marcello B. O. Silva ${ }^{1}$, Christian N. Berlinck ${ }^{l}$
}

${ }^{1}$ Chico Mendes Institute for Biodiversity Conservation (ICMBio), Brasília, Brazil
*Correspondence to: camila.s-silva.terceirizada@icmbio.gov.br

\begin{abstract}
The fire management went through a ripening process. Initially, the exclusion of fire was the strategy of environmental preservation, but it resulted in accumulation of biomass fuel and severe fires. It sought to integrate fire with ecological and socioeconomic needs, an alternative rather than excluding the fire for conservation called by the Integrated Fire Management (IFM). In Brazil, this approach has been applied since 2012 with significant changes in governmental and community acceptance. Therefore, this paper reports the outcomes of the IFM in Federal Protected Areas (PAs). In 2014, only the Serra Geral do Tocantins Ecological Station and Chapada das Mesas National Park worked from the perspective of IFM. In 2017, 53 PAs planned their actions through the elaboration of Fire Management Plans (IFMP). Today, almost 200 PAs made their IFMP, of which, 44\% have hired fire brigade. The hiring of specialized personnel was favored by Law No. 13,668/2018 which extends the contract term from 6 months to 3 years. The hiring of almost 1,200 wildland firefighters, mainly members of the local population, values the traditional and regional knowledge and contributes with the income linked to conservation. With the increasing consolidation of the IFM, there is a constant generation and exchange of knowledge and experiences between managers and institutions, boosting the development of techniques such as the fuel load mapping. The dissemination of knowledge occurs through exchanges and training cycles of public federal servers, firefighters and volunteers/community, training about 2,500 people/year. That generated many strategies for the reduction of fires, such as in the Serra da Canastra National Park, which started authorizing controlled burnings for producers, reducing recurrent tensions between managers and community; and the Campos Amazônicos National Park, with prescribed burnings (PBs). Those actions contributed for the reduction of 51\% and 90\% of burned area (2010/2018), respectively, protection of sensitive vegetation, springs/veredas, threatened species and reduction of GHG emissions. Another 25 PAs performed PBs in 2018 and 40 intend to execute them in 2019. The IFM is becoming consolidated. However it is still necessary to continue learning from the results to fit the best strategy for each area.
\end{abstract}

Keywords: Federal Protected Areas and Integrated Fire Management. 